\title{
Prone positioning combined with high-flow nasal cannula in severe noninfectious ARDS
}

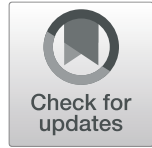

Orlando R. Pérez-Nieto ${ }^{1}$, Manuel A. Guerrero-Gutiérrez ${ }^{2}$, Ernesto Deloya-Tomas ${ }^{1}$ and Silvio A. Ñamendys-Silva ${ }^{2,3,4^{*}}$ (D)

Dear editor,

We have read with exceptional interest the manuscript of Lin Ding et al. because the use of noninvasive ventilation (NIV) and high flow-nasal cannula (HFNC) combined with the prone position (PP) could avoid intubation of patients with acute respiratory distress syndrome (ARDS) [1].

The prone position is associated with a decrease in mortality in patients with ARDS, as demonstrated by Guerin in 2013 and the Formal Guide to the treatment of ARDS recommended the use of the PP for at least $16 \mathrm{~h}$ a day when $\mathrm{P} / \mathrm{F}<150$ (moderate-severe ARDS) [2]. A study with a sample of 20 healthy patients shows an increase in lung volume at the end of expiration (LVEE) and a decrease in respiratory rate using HFNC demonstrated by electrical impedance tomography and that a PP resulted a more homogeneous distribution of the LVEE than the supine position [3].

The etiology of ARDS reported by Ding and colleagues [1] includes infectious pathologies in all cases, demonstrating that an early PP strategy with HFNC or NIV is safe and effective in patients with moderate ARDS and with $\mathrm{SpO}_{2}>95 \%$ in which intubation could be avoided.
The mortality of ARDS associated with infectious etiology (pneumonia, influenza, and sepsis) is considerably higher $(35.1 \%$ for pulmonary infection and $28.1 \%$ for sepsis) than that reported for noninfectious causes such as pneumonitis (6.4\%) and trauma (2.5\%) [4]; therefore, an early PP strategy combined with HFNC could theoretically be effective in these cases, even with $\mathrm{P} / \mathrm{F}<100$.

We present a multicenter retrospective series of 6 cases of patients with severe ARDS with a noninfectious etiology compiled in 2017 and 2018 in hospitals of the 2nd level of care to which the PP was applied with HFNC or NIV. The PP was applied for $2-3 \mathrm{~h}$ every $12 \mathrm{~h}$ for 2 days, and in 3 cases, it was possible to avoid intubation; the causes were thoracic trauma with pulmonary contusions, lupus pneumonitis, bone marrow transplantation, and atelectasis of unknown cause (Table 1) (Fig. 1).

The PP with HFNC or NIV seems to be a promising strategy to avoid intubation and its complications in patients with severe ARDS of noninfectious etiology, and a randomized controlled study is required to assess its safety and efficacy. The results of the OPTIPRONE study on the use of PP combined with HFNC in patients with ARDS with $\mathrm{PaO}_{2} / \mathrm{FiO}_{2}<200$ [5] are expected.

* Correspondence: snamendyss@medicasur.org.mx

This comment refers to the article available at https://doi.org/10.1186/ s13054-020-2738-5.

${ }^{2}$ Department of Critical Care Medicine, Instituto Nacional de Cancerologia,

Mexico City, Mexico

${ }^{3}$ Department of Critical Care Medicine, Instituto Nacional de Ciencias

Medicas y Nutricion Salvador Zubiran, Mexico City, Mexico

Full list of author information is available at the end of the article

(c) The Author(s). 2020 Open Access This article is licensed under a Creative Commons Attribution 4.0 International License, which permits use, sharing, adaptation, distribution and reproduction in any medium or format, as long as you give appropriate credit to the original author(s) and the source, provide a link to the Creative Commons licence, and indicate if changes were made. The images or other third party material in this article are included in the article's Creative Commons licence, unless indicated otherwise in a credit line to the material. If material is not included in the article's Creative Commons licence and your intended use is not permitted by statutory regulation or exceeds the permitted use, you will need to obtain permission directly from the copyright holder. To view a copy of this licence, visit http://creativecommons.org/licenses/by/4.0/ The Creative Commons Public Domain Dedication waiver (http://creativecommons.org/publicdomain/zero/1.0/) applies to the data made available in this article, unless otherwise stated in a credit line to the data. 
Table 1 Clinical characteristics and outcomes of patients

\begin{tabular}{|c|c|c|c|c|c|c|c|c|c|c|c|}
\hline $\begin{array}{l}\text { Case } \\
\text { no. }\end{array}$ & Gender & $\begin{array}{l}\text { Age } \\
\text { (years) }\end{array}$ & $\begin{array}{l}\text { Cause of } \\
\text { ARDS }\end{array}$ & $\begin{array}{l}\text { Ventilatory } \\
\text { support }\end{array}$ & $\begin{array}{l}\text { BaselinePaO2/ } \\
\mathrm{FiO} 2(\mathrm{P} / \mathrm{F}) \\
(\mathrm{mmHg})\end{array}$ & $\begin{array}{l}\text { Baseline } \\
\text { S/F }\end{array}$ & $\begin{array}{l}\text { P/F after prone } \\
\text { position with } \\
\text { HFNC o NIV }\end{array}$ & $\begin{array}{l}\text { S/F after prone } \\
\text { position with } \\
\text { HFNC or NIV }\end{array}$ & $\begin{array}{l}\text { Beginning } \\
\text { of prone } \\
\text { position and } \\
\text { HFNC or NIV }\end{array}$ & Intubation & Outcome \\
\hline 1 & Male & 33 & $\begin{array}{l}\text { Closed thorax } \\
\text { trauma }\end{array}$ & HFNC & - & 195 & - & 213 & $<24 h$ & No & Survive \\
\hline 2 & Female & 19 & $\begin{array}{l}\text { Lupus } \\
\text { pneumonitis }\end{array}$ & HFNC & 91 & 133 & 150 & 165 & $<24 h$ & No & Survive \\
\hline 3 & Male & 56 & $\begin{array}{l}\text { Open thorax } \\
\text { trauma }\end{array}$ & HFNC & 80 & 98 & 101 & 128 & $48 \mathrm{~h}$ & Yes & Survive \\
\hline 4 & Female & 36 & $\begin{array}{l}\text { Bone marrow } \\
\text { transplant }\end{array}$ & NIV & 67 & 87 & 96 & 155 & $72 \mathrm{~h}$ & Yes & Death \\
\hline 5 & Male & 45 & $\begin{array}{l}\text { Bilateral } \\
\text { atelectasis }\end{array}$ & NIV & 89 & 150 & - & 250 & $72 \mathrm{~h}$ & No & Survive \\
\hline 6 & Male & 24 & $\begin{array}{l}\text { Near } \\
\text { drowning }\end{array}$ & HFNC & 75 & 93 & 131 & 188 & $<24 h$ & No & Survive \\
\hline
\end{tabular}

ARDS acute respiratory distress syndrome, S/F oxygen saturation ratio by pulse oximetry between inspired oxygen fraction, HFNC high-flow nasal cannula, NIV noninvasive ventilation

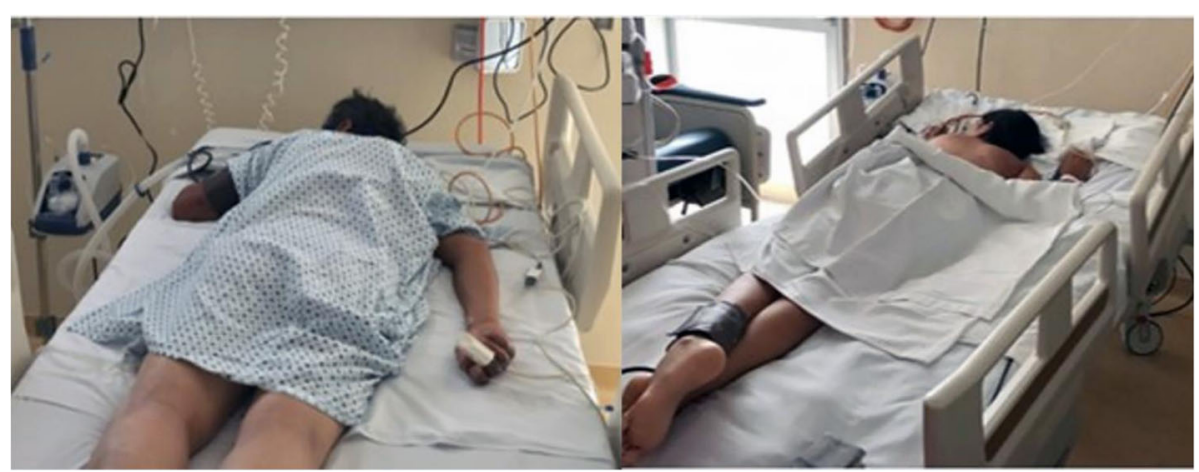

Fig. 1 Patients with ARDS with high flow oxygen cannula and prone position

\section{Authors' response}

Lin Ding and Hangyong $\mathrm{He}$

We appreciate the time the authors have taken to read and comment on our recent article published in critical care [6].

First of all, which etiology of acute respiratory distress syndrome (ARDS) should be the most appropriate group treated with prone position (PP) combined with high-flow nasal cannula (HFNC)? In our study, the majority of ARDS were caused by infectious disease. And we totally agree that PP combined with HFNC should be tried in noninfectious ARDS patients, which was reported in previous studies and case series [7-9]. However, as reported by Perez-Nieto et al., the use of prone positioning of the patients with complex chest traumas and post status of thoracic surgery is sparse and relatively controversial [8]. Thus, its safety should be evaluated in these noninfectious ARDS population with special protocol.
Another question is whether it is safe and effective enough for patients with noninfectious ARDS with $\mathrm{PaO}_{2} /$ $\mathrm{FiO}_{2}<100$. PP is a respiratory support technique but not for treating the causative disease which induced ARDS. Thus, as reported in the case series of Perez-Nieto et al., some group of noninfectious ARDS caused by autoimmune diseases (such as lupus pneumonitis) may need a longer duration of disease resolving than infectious disease and may present with deterioration even under PP and HFNC therapy. And patients with $\mathrm{PaO}_{2} / \mathrm{FiO}_{2}<100$ may face a delayed intubation and worse outcome. Therefore, the safety and efficacy of PP combined with HFNC in noninfectious diseases which cause severe ARDS in patients with a $\mathrm{PaO}_{2} / \mathrm{FiO}_{2}<100$ also need evaluation.

\section{Acknowledgements}

We would like to thank Dr. Octavio Lescas, Dr. Raymundo Flores, and Dr. Eder Zamarron for his contribution to the treatment of the patients. 


\section{Authors' contributions}

ORPN designed the paper. MAGG redacted the paper. SAÑ-S critically reviewed the paper, and the rest of the authors participated in the drafting of the paper. The authors read and approved the final version of the manuscript.

\section{Funding}

No funding to report.

\section{Availability of data and materials}

Not applicable.

Ethics approval and consent to participate

Not applicable.

\section{Consent for publication}

Not applicable.

\section{Competing interests}

The authors declare that they have no competing interests.

\section{Author details}

'General Hospital of San Juan del Rio and Santo Tomas Hospital. Intensive care unit, Queretaro, Mexico. ${ }^{2}$ Department of Critical Care Medicine, Instituto Nacional de Cancerologia, Mexico City, Mexico. ${ }^{3}$ Department of Critical Care Medicine, Instituto Nacional de Ciencias Medicas y Nutricion Salvador Zubiran, Mexico City, Mexico. ${ }^{4}$ Department of Critical Care Medicine, Hospital Medica Sur, 14050 Mexico City, Mexico.

Received: 15 February 2020 Accepted: 6 March 2020

\section{Published online: 23 March 2020}

\section{References}

1. Ding L, Wang L, Ma W, He H. Efficacy and safety of early prone positioning combined with HFNC or NIV in moderate to severe ARDS: a multi-center prospective cohort study. Crit Care. 2020;24(1):28. Published 2020 Jan 30. https://doi.org/10.1186/s13054-020-2738-5.

2. Papazian L, Aubron C, Brochard L, et al. Formal guidelines: management of acute respiratory distress syndrome. Ann Intensive Care. 2019;9(1):69. Published 2019 Jun 13. https://doi.org/10.1186/s13613-019-0540-9.

3. Riera J, Pérez P, Cortés J, Roca O, Masclans JR, Rello J. Effect of high-flow nasal cannula and body position on end-expiratory lung volume: a cohort study using electrical impedance tomography. Respir Care. 2013;58(4):58996. https://doi.org/10.4187/respcare.02086.

4. Cochi SE, Kempker JA, Annangi S, Kramer MR, Martin GS. Mortality trends of acute respiratory distress syndrome in the United States from 1999 to 2013. Ann Am Thorac Soc. 2016;13(10):1742-51. https://doi.org/10.1513/ AnnalsATS.201512-8410C.

5. ClinicalTrials.gov. Antonelli Massimo. Prone positioning during high flow oxygen therapy in acute hypoxemic respiratory failure (Optiprone). https:// clinicaltrials.gov/ct2/show/NCT03095300. Accessed 12 Feb 2020.

6. Ding L, Wang L, Ma W, He H. Efficacy and safety of early prone positioning combined with HFNC or NIV in moderate to severe ARDS: a multi-center prospective cohort study. Crit Care. 2020;24(1):28

7. Dupont $\mathrm{H}$, Mentec $\mathrm{H}$, Cheval C, Moine P, Fierobe L, Timsit JF. Short-term effect of inhaled nitric oxide and prone positioning on gas exchange in patients with severe acute respiratory distress syndrome. Crit Care Med. 2000;28(2):304-8.

8. Sahoo AK, Tripathy S, Singh SK. Prone ventilation in a patient with severe ARDS having a floating sternum. BMJ Case Rep. 2019;12(3):e227892. Published 2019 Mar 12. https://doi.org/10.1136/bcr-2018-227892.

9. Oto B, Orosco RI, Panter E, Velamuri R, Kar AR, Caffrey J. Prone positioning of the burn patient with acute respiratory distress syndrome: a review of the evidence and practical considerations. J Burn Care Res. 2018;39(3):471-5.

\section{Publisher's Note}

Springer Nature remains neutral with regard to jurisdictional claims in published maps and institutional affiliations. 